\title{
Effects of selected food phytochemicals in reducing the toxic actions of TCDD and $p, p^{\prime}$-DDT in U937 macrophages
}

\author{
Eric M. Sciullo $\cdot$ Christoph F. Vogel $\cdot$ Dalei Wu • \\ Akira Murakami · Hajime Ohigashi · \\ Fumio Matsumura
}

Received: 9 August 2010 / Accepted: 8 September 2010 / Published online: 24 September 2010

(c) The Author(s) 2010. This article is published with open access at Springerlink.com

\begin{abstract}
To assess the effectiveness of selected food phytochemicals in reducing the toxic effects of the environmental toxicants, 2,3,7,8-tetrachlorodibenzo-p-dioxin (TCDD) and $p, p^{\prime}$-DDT (DDT), we tested the potencies of auraptene, nobiletin, zerumbone, and $( \pm)$-13-hydroxy-10-oxo-trans11-octadecenoic acid (13-HOA) in reversing the inflammatory action of these toxicants in U937 human macrophages. Using quantitative RT-PCR as the initial screening assay, we identified antagonistic actions of zerumbone and auraptene against the action of TCDD and DDT in up-regulating the mRNA expressions of COX-2 and VEGF. The functional significance of the inhibitory action of zerumbone on COX-2 expression was confirmed by demonstrating its suppression of TCDD-induced activation of COX-2 gene expression in mouse MMDD1 cells. We tested auraptene on DDT-induced reactive oxygen species (ROS) formation in U937 macrophages and found that auraptene is a powerful agent antagonizing this action of DDT. To confirm the significance of these actions of zerumbone and auraptene at
\end{abstract}

\author{
E. M. Sciullo · C. F. Vogel · D. Wu · F. Matsumura $(\bowtie)$ \\ Department of Environmental Toxicology, \\ University of California Davis, 3792 Old Davis Rd, \\ Davis, CA 95616, USA \\ e-mail: fmatsumura@ucdavis.edu \\ C. F. Vogel · F. Matsumura \\ Center for Health and The Environment, \\ University of California Davis, 3792 Old Davis Rd, \\ Davis, CA 95616, USA \\ A. Murakami $\cdot$ H. Ohigashi \\ Division of Food Science and Biotechnology, \\ Graduate School of Agriculture, Kyoto University, Kyoto, Japan \\ H. Ohigashi \\ Department of Bioscience, \\ Fukui Prefectural University, Fukui City, Japan
}

the cellular level, we assessed their influence on TCDDinduced apoptosis resistance in intact U937 macrophages and found that they are capable of reversing this action of TCDD. In conclusion, zerumbone and auraptene were identified to be the most effective agents in protecting U937 macrophages from developing these cell toxic effects of TCDD and DDT.

Keywords Food phytochemicals - TCDD, DDT, macrophages $\cdot$ Inflammatory responses $\cdot \mathrm{AhR} \cdot \mathrm{COX}-2$

\section{Introduction}

Among major environmental pollutants, dioxin, 2,3,7,8tetrachlorodibenzo-p-dioxin (referred to as TCDD) and $p, p^{\prime}$-DDT (referred to as DDT) are two of the most widely distributed chemicals that are frequently found in human tissues. Both chemicals have been considered to cause deleterious human health effects and therefore there is a great need to find effective methods to prevent or to ameliorate their toxicities. Among those tried so far, certain phytochemicals appear to offer some promise (Ashida 2000; Murakami and Ohigashi 2007). For this purpose, the most preferred type of phytochemicals would be those that are found among edible plants because of the future possibility of ingesting such natural products as a part of diet or as food supplements. As for the nature of toxic actions of dioxin and DDT, the best known biochemical indicators are increased production of reactive oxygen species (ROS), bioactive prostaglandins, pro-inflammatory cytokines, and a host of oxidative metabolic enzymes (Perez-Maldonado et al. 2005; Slaninova et al. 2009). ROS can activate NF $\kappa$ B, a key transcription factor in the inflammatory response, as well as a wide milieu of proteins engaged in oxidative and 
antioxidative response reactions. Prostaglandins are formed from the activities of the cyclooxygenase enzymes (COX-1 and COX-2), which have been shown to be one of the major types of mediators of inflammation induced by TCDD (Kraemer et al. 1996; Vogel et al. 1997). Additionally, TCDD also causes induction of TNF- $\alpha$ production as an autocrine factor (Charles and Shiverick 1997), which appears to contribute greatly to the toxic manifestation of TCDD in mice (Taylor et al. 1992). TNF- $\alpha$ through binding to its specific receptor is capable of activating $N F \kappa B$, which is well known to induce further activation of gene transcription of a number of pro-inflammatory cytokines and chemokines such as IL-8 (Lappas et al. 2002).

In this study, we have compared the effects of four different phytochemicals from edible plants (see Fig. 1 for their chemical structures) in terms of their ability to alter a selected list of mRNA expressions that are used here as the markers of mostly inflammatory responses from macrophages to these two pollutants. The reasons why we have chosen U937 human macrophages as the primary test model were that first macrophages are known to play pivotal roles in eliciting inflammatory responses and second we have already good background information on the action spectra of cell stress responses elicited by TCDD in this cell line (Vogel et al. 2005; Sciullo et al. 2008). Accordingly, the main objectives of this study have been set to be: (a) to find the most effective phytochemical to suppress the actions of both DDT and TCDD as judged by TCDD- or DDT-induced changes in expression of mRNA markers of cell stress signaling assessed through the quantitative RT-PCR approach, and (b) to confirm the main findings from the above screening tests through the use of assays that are designed to detect the functional changes occurring among those markers as the result of action of TCDD and DDT.

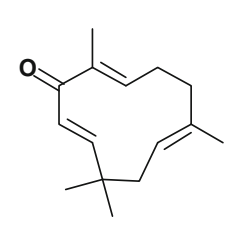

ZER

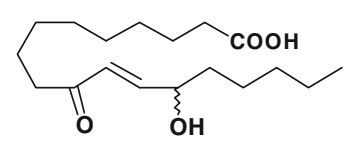

13-HOA

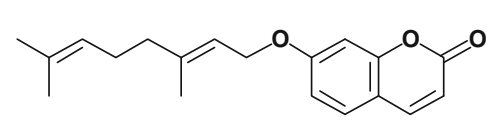

AUR

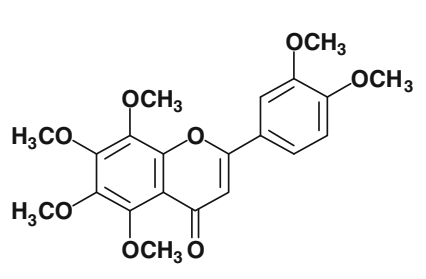

NOB
Fig. 1 Chemical structures of the chemopreventive phytochemical compounds used

\section{Materials and methods}

Materials

2,3,7,8-tetrachlorodibenzo( $p$ )dioxin (TCDD; >99\% purity) was originally obtained from Dow Chemicals Co. (Midland, MI). 1,1,1-trichloro-2,2-bis(4-chlorophenyl)ethane ( $p, p^{\prime}$ DDT) was obtained from AccuStandard Inc. and was prepared as $1 \mathrm{mM}$ stocks in ethanol. Dimethyl sulfoxide $\left(\mathrm{Me}_{2} \mathrm{SO}\right)$, 2,7-dichloro-dihydrofluorescein (DCFH) and phorbol-12-myristate-13-acetate (TPA) were purchased from Sigma-Aldrich (St. Louis, MO). Antibodies specific to C/EBP $\alpha, \beta$, and $\delta$ were purchased from Santa Cruz Biotechnology (Santa Cruz, CA). Luteolin was purchased from Calbiochem (440025). JetPei transfection reagent was purchased from Polyplus Transfection Inc. (New York, NY). Zerumbone, auraptene, nobiletin, and $( \pm)$-13-hydroxy-10oxo-trans-11-octadecenoic acid (13-HOA) were by Dr. Akira Murakami (Kyoto University, Division of Food Science and Biotechnology, Japan), and their chemical structures are shown in Fig. 1. The mouse COX-2-luc plasmids were kindly provided by H. Herschman, Department of Molecular and Medical Pharmacology, University of California-Los Angeles, Los Angeles, CA. Other molecular biological reagents were purchased from Qiagen (Valencia, CA) and Roche (Indianapolis, IN).

\section{Cell culture and treatments}

Human U937 monocytic cells were obtained from A.T.C.C. (Manassas, VA) and maintained in RPMI 1640 medium (Invitrogen, Carlsbad, CA) containing 10\% fetal bovine serum (Invitrogen), supplemented with $4.5 \mathrm{~g} / \mathrm{l}$ glucose (Sigma), $1 \mathrm{mM}$ sodium pyruvate (Invitrogen), and $10 \mathrm{mM}$ HEPES (Invitrogen). Cell culture was maintained at a cell density between $2 \times 10^{5}$ and $2 \times 10^{6}$ cells $/ \mathrm{ml}$. For differentiation into monocytes/macrophages, U937 cells were treated with TPA $(5 \mu \mathrm{g} / \mathrm{ml})$ and allowed to adhere for $48 \mathrm{~h}$ in a $5 \% \mathrm{CO}_{2}$ tissue culture incubator at $37^{\circ} \mathrm{C}$, after which they were fed with TPA-free medium. MMDD1 cells were kindly provided by Dr. Jurgen Schnermann (National Institutes of Health, Bethesda, Maryland). They were grown in Dulbecco's modified Eagle's medium supplemented with $10 \%$ fetal calf serum and antibiotics. Cells were routinely incubated at $37^{\circ} \mathrm{C}$ with $5 \% \mathrm{CO}_{2}$, and medium was changed every 2 days. Cells were pre-treated for $1 \mathrm{~h}$ prior to the addition of TCDD or DDT for all phytochemicals tested. All mRNAs were detected using qRT-PCR approaches (see below). The concentrations of all test phytochemicals at their most concentrated dose utilized $(10 \mu \mathrm{M}$ zerumbone. $20 \mu \mathrm{M}$ auraptene, $50 \mu \mathrm{M}$ nobiletin and $20 \mu \mathrm{M} 13-\mathrm{HOA}$, respectively) were non-cytotoxic to U937 macrophages under our test condition. The effects of the environmental 
pollutants were compared always against $0.1 \%$ DMSOtreated controls.

Luciferase assays

MMDD1 cells were seeded in 24-well plate at $1 \times 10^{4} /$ well. After about $60 \mathrm{~h}$, medium was refreshed, and cells were transfected with $0.5 \mu \mathrm{g}$ plasmid in each well using JetPEI regent for $1 \mathrm{~h}$. Then, medium was refreshed and $2 \mu \mathrm{M}$ zerumbone was added $1 \mathrm{~h}$ before $10 \mathrm{nM}$ TCDD treatment in each well. Cells were incubated in the next $20 \mathrm{~h}$ before they were washed with PBS and lysed in $150 \mu 1$ lysis buffer. Luciferase activities were measured with the Luciferase Assay System (Promega Co., Madison, WI) using a luminometer (Berthold Lumat LB 9501/16, Pittsburgh, PA).

\section{Quantitative real-time reverse transcriptase PCR}

The oligonucleotide sequences of primers used for detecting all of the marker mRNA expressions are shown in Table 1. Total RNA was isolated from U937 macrophages using a high pure RNA isolation kit (Qiagen), and cDNA synthesis was carried out as previously described (Vogel et al. 2004a). Quantitative detection of target gene mRNAs was performed with a LightCycler Instrument (Roche Diagnostics, Mannheim, Germany) using the QuantiTect SYBR Green PCR Kit (Qiagen, Valencia, CA) according to the manufacturer's instructions. DNA-free total RNA $(1.0 \mu \mathrm{g})$ was reverse-transcribed using $4 \mathrm{U}$ Omniscript reverse transcriptase (Qiagen, Valencia, CA) and $1 \mu \mathrm{g}$ oligo(dT) ${ }_{15}$ in a final volume of $40 \mu \mathrm{l}$. The primers for each gene were designed on the basis of the respective cDNA or mRNA sequences using OLIGO primer analysis software, provided by Steve Rozen and Whitehead Institute/MIT Center for Genome Research (Rozen and Skaletsky 2003).

Table 1 Nucleotide mRNA sequences for target human genes used in qRT-PCR approaches

\begin{tabular}{ll}
\hline Gene & Sequence \\
\hline$\beta$-ACTIN & FP: 5'-GGACTTCGAGCAAGAGATGG-3' \\
& RP: 5'-AGCACTGTGTTGGCGTACAG-3' \\
COX-2 & FP: 5'-TGAAACCCACTCCAAACACA-3' \\
& RP: 5'-GAGAAGGCTTCCCAGCTTTT-3' \\
CYP1A1 & FP: 5'-TAGACACTGATCTGGCTGCAG-3' \\
& RP: 5'-GGGAAGGCTCCATCAGCATC-3' \\
VEGF & FP: 5'-AAGGAGGAGGGCAGAATCAT-3' \\
& RP: 5'-ATCTGCATGGTGATGTTGGA-3' \\
MMP-3 & FP: 5'-AACCTGTCCCTCCAGAACCT-3' \\
& RP: 5'-GGAAGAGATGGCCAAAATGA-3' \\
TNF- $\alpha$ & FP: 5'-TCCTTCAGACACCCTCAACC-3' \\
& RP: 5'-AGGCCCCAGTTTGAATTCTT-3' \\
\hline
\end{tabular}

See Table 1 for a complete list of sequences designed according to this method. PCR amplification was carried out in a total volume of $20 \mu \mathrm{l}$, containing $2 \mu \mathrm{l}$ of cDNA, $10 \mu \mathrm{l}$ of $2 \times$ QuantiTect SYBR Green PCR Master Mix, and $0.2 \mu \mathrm{M}$ of each primer. The PCR cycling conditions were $95^{\circ} \mathrm{C}$ for $15 \mathrm{~min}$ followed by $30-40$ cycles of $94^{\circ} \mathrm{C}$ for $15 \mathrm{~s}, 60^{\circ} \mathrm{C}$ for $20 \mathrm{~s}$, and $72^{\circ} \mathrm{C}$ for $10 \mathrm{~s}$. Detection of the fluorescent product was performed at the end of the $72^{\circ} \mathrm{C}$ extension period. Negative controls were run concomitantly to confirm that the samples were not cross-contaminated. A sample with DNase- and RNase-free water instead of RNA was concomitantly examined for each of the reaction units described earlier. To confirm the amplification specificity, the PCR products were subjected to melting curve analysis. All PCR assays were performed in duplicate or triplicate. The intra-assay variability was $<7 \%$. For quantification, data were analyzed with the LightCycler analysis software according to the manufacturer's instructions. The variables were examined for one-sided Student's $t$-test. The results are given as the mean $\pm \mathrm{SE}$.

\section{Electrophoretic gel mobility shift assay (EMSA)}

Nuclear extracts were isolated from human U937 macrophages. In brief, $5 \times 10^{6}$ cells were treated with $10 \mathrm{nM}$ TCDD for $1 \mathrm{~h}$ and harvested in Dulbecco's PBS containing $1 \mathrm{mM}$ phenylmethylsulfonyl fluoride and $0.05 \mu \mathrm{g} / \mu \mathrm{l}$ aprotinin. After centrifugation, the cell pellets were gently resuspended in $1 \mathrm{ml}$ of hypotonic buffer $(20 \mathrm{mM}$ HEPES, $20 \mathrm{mM} \mathrm{NaF}, 1 \mathrm{mM} \quad \mathrm{Na}_{3} \mathrm{VO}_{4}, 1 \mathrm{mM} \quad \mathrm{Na}_{4} \mathrm{P}_{2} \mathrm{O}_{7}, 1 \mathrm{mM}$ EDTA, $1 \mathrm{mM}$ EGTA, $0.5 \mathrm{mM}$ phenylmethylsulfonyl fluoride, $0.13 \mu \mathrm{M}$ okadaic acid, $1 \mathrm{mM}$ dithiothreitol, $\mathrm{pH} 7.9$, and $1 \mu \mathrm{g} / \mathrm{ml}$ each leupeptin, aprotinin, and pepstatin). The cells were allowed to swell on ice for $15 \mathrm{~min}$ and then homogenized by 25 strokes of a Dounce homogenizer. After centrifugation for $1 \mathrm{~min}$ at $16,000 \mathrm{~g}$, nuclear pellets were resuspended in $300 \mu \mathrm{l}$ of ice-cold high salt buffer (hypotonic buffer with $420 \mathrm{mM} \mathrm{NaCl}$ and $20 \%$ glycerol). The samples were passed through a 21-gauge needle and stirred for $30 \mathrm{~min}$ at $4^{\circ} \mathrm{C}$. The nuclear lysates were microcentrifuged at $16,000 \mathrm{~g}$ for $20 \mathrm{~min}$, aliquoted, and stored at $-70^{\circ} \mathrm{C}$. Protein concentrations were determined by the Bradford method. Oligonucleotides and EMSA were performed as described previously (Vogel et al. 2007).

\section{Apoptosis assay}

U937 monocyte cells were seeded at $1 \times 10^{4}$ cells in 12-well culture plates. After treatment for $48 \mathrm{~h}$ with $10 \mathrm{nM}$ TCDD, apoptosis was induced by UV light $\left(100 \mu \mathrm{J} / \mathrm{cm}^{2}\right)$ for $1 \mathrm{~min}$. After $4 \mathrm{~h}$, cells were collected by centrifugation for $5 \mathrm{~min}$ at $350 \mathrm{~g}$. A total of $2 \times 10^{5}$ cells were re-suspended in $50 \mu \mathrm{l}$ of $1 \times$ annexin $\mathrm{V}$ binding buffer $(10 \mathrm{mmol} / \mathrm{l}$ HEPES, $\mathrm{pH}$ 
7.4, $140 \mathrm{mmol} / \mathrm{l} \mathrm{NaCl}$, and $2.5 \mathrm{mmol} / \mathrm{l} \mathrm{CaCl}_{2}$ ) supplemented with $5 \mu \mathrm{l}$ of annexin $\mathrm{V}$ fluorescein isothiocyanate (Sigma) and $5 \mu \mathrm{l}$ of propidium iodide (PI) solution $(50 \mu \mathrm{g} / \mathrm{ml})$. The cells were gently mixed and incubated for $10 \mathrm{~min}$ at room temperature in the dark. Apoptotic cells were counted directly by using the fluorescence microscope (Leitz, Wetzlar, Germany). In each experiment, three representative aliquots per cell line are counted for analysis. Both annexin $\mathrm{V}$ positive and annexin V-PI-double-positive cells were considered to be apoptotic.

\section{Intracellular ROS detection}

Intracellular oxidative stress was measured by DCFH (2, 7-dichlorofluorescein diacetate) oxidation. DCFH-DA enters cells passively and is deacetylated by esterase to non-fluorescent DCFH. DCFH reacts with ROS to form DCF, the fluorescent product. DCFH-DA was dissolved in methanol at $2 \mathrm{mM}$ and was diluted 100-fold in PBS to give DCFH-DA at $20 \mu \mathrm{M}$. U937 macrophage cells were seeded in a 96-well plate. The cells were exposed to DCFH-DA for $1 \mathrm{~h}$ at $37^{\circ} \mathrm{C}$ and then treated with either $10 \mathrm{nM}$ TCDD or $1 \mu \mathrm{M} p, p^{\prime}$-DDT for $40 \mathrm{~min}$. Auraptene was used at $20 \mu \mathrm{M}$ and was co-treated with the appropriate pollutant. The fluorescence was read immediately at wavelengths of $485 \mathrm{~nm}$ for excitation and $530 \mathrm{~nm}$ for emission on a Mithras 940LB fluorescent plate reader. The value subtracted by control group was viewed as the increase in intracellular ROS.

\section{Statistical analysis}

All experiments were repeated for a minimum of three times, and results were expressed as mean \pm standard deviation. Statistical differences were determined by student's $t$-test, and for the analysis of the significance between pairs of mean values, the Bonferroni post hoc test was applied.

\section{Results and discussion}

Effects of phytochemicals on CYP1A1 mRNA expression

CYP1A1 is an appropriate marker in this work as a result of its unique association and induction following AhR activation (Hankinson 2005). Of all phytochemicals tested, nobiletin and to a lesser extent auraptene are the only ones that significantly reduced the action of both DDT and TCDD to induce the expression of CYP1A1 mRNAs (Fig. 2a). In their presence, the effect of DDT to induce this marker expression was not statistically significant.

\section{Effects of phytochemicals on COX-2 mRNA expression}

COX-2 is used as a biomarker in this study because of its known role in inflammatory signaling and prostaglandin synthesis (Altinoz and Korkmaz 2004), and our past experience that it represents the pivotal event for the toxic action of TCDD to trigger a cascade of inflammatory reactions, leading to the etiology of serious toxic consequences (Sciullo et al. 2008; Vogel et al. 2004a; Nishimura et al. 2008; Dong et al. 2010). Zerumbone treatment significantly attenuated the toxic actions of TCDD and DDT to induce COX-2 mRNA expressions after $24 \mathrm{~h}$ (Fig. 2b). Auraptene has also shown significant antagonistic effects on the action of DDT and to a lesser extent on the action of TCDD. While other phytochemicals caused some reduction on the amplitude of induction of this marker, their effects were not as significant.

\section{Effects of phytochemicals on TNF- $\alpha$ mRNA expression}

TNF- $\alpha$ expression is used in this study as an indicator of inflammatory signaling through activation of the NFkB pathway (Inoue et al. 2006). As far as induction of TNF- $\alpha$ by these two pollutants is concerned, the only phytochemical effective in antagonizing their actions was 13-HOA (Fig. 2c). No other chemicals showed any suppressive effects on this marker. Such an action of 13-HOA indicates a unique property of this phytochemical not found in others as far as we have tested.

Effects of phytochemicals on MMP-3 mRNA expression

MMP-3 has been selected because of its known roles in macrophages to affect tissue inflammation and damage, notably through its role in extracellular matrix degradation contributing to the etiology of cardiovascular disease (Shibuya 2006). The effect of these two pollutants to induce this marker expression was most significantly attenuated by zerumbone (Fig. 2d). In its presence, neither TCDD nor DDT showed any inducing action of this marker. 13-HOA also significantly blocked MMP-3 mRNA induction, its effect particularly noticeable on its induction by $1 \mu \mathrm{M}$ DDT for $24 \mathrm{~h}$ (Fig. 2d).

\section{Effects of phytochemicals on VEGF mRNA expression}

VEGF has been selected for its role in macrophagemediated angiogenesis and inflammation (Matsunaga et al. 2004). The action of these two pollutants to induce this mRNA marker was attenuated by zerumbone, auraptene, and 13-HOA (Fig. 2e). Zerumbone was more effective in attenuating the effect of TCDD among all phytochemicals compared, but auraptene affected that of DDT with greater potency. 13-HOA, on the other hand, did not affect the action of TCDD, just affecting that of DDT to a lesser extent than zerumbone or auraptene. 
Fig. 2 Effects of $10 \mu \mathrm{M}$ zerumbone (ZER), $20 \mu \mathrm{M}$ auraptene $(A U R), 50 \mu \mathrm{M}$ nobiletin $(N O B)$, and $20 \mu \mathrm{M}( \pm)$-13-hydroxy-10oxo-trans-11-octadecenoic acid (13-HOA) against the actions of $1 \mu \mathrm{M} p, p^{\prime}$-DDT or $10 \mathrm{nM}$ TCDD for $24 \mathrm{~h}$ in a U937 macrophage model for a CYP1A1, b COX-2, c TNF- $\alpha$, d MMP-3, and e VEGF mRNAs. mRNAs for selected genes were compared using qRT-PCR approaches and normalized against $\beta$-actin. *Treatment significantly different from controls $P<0.05$. $a$ Treatment significantly different from TCDD or DDT treatment alone $P<0.05$
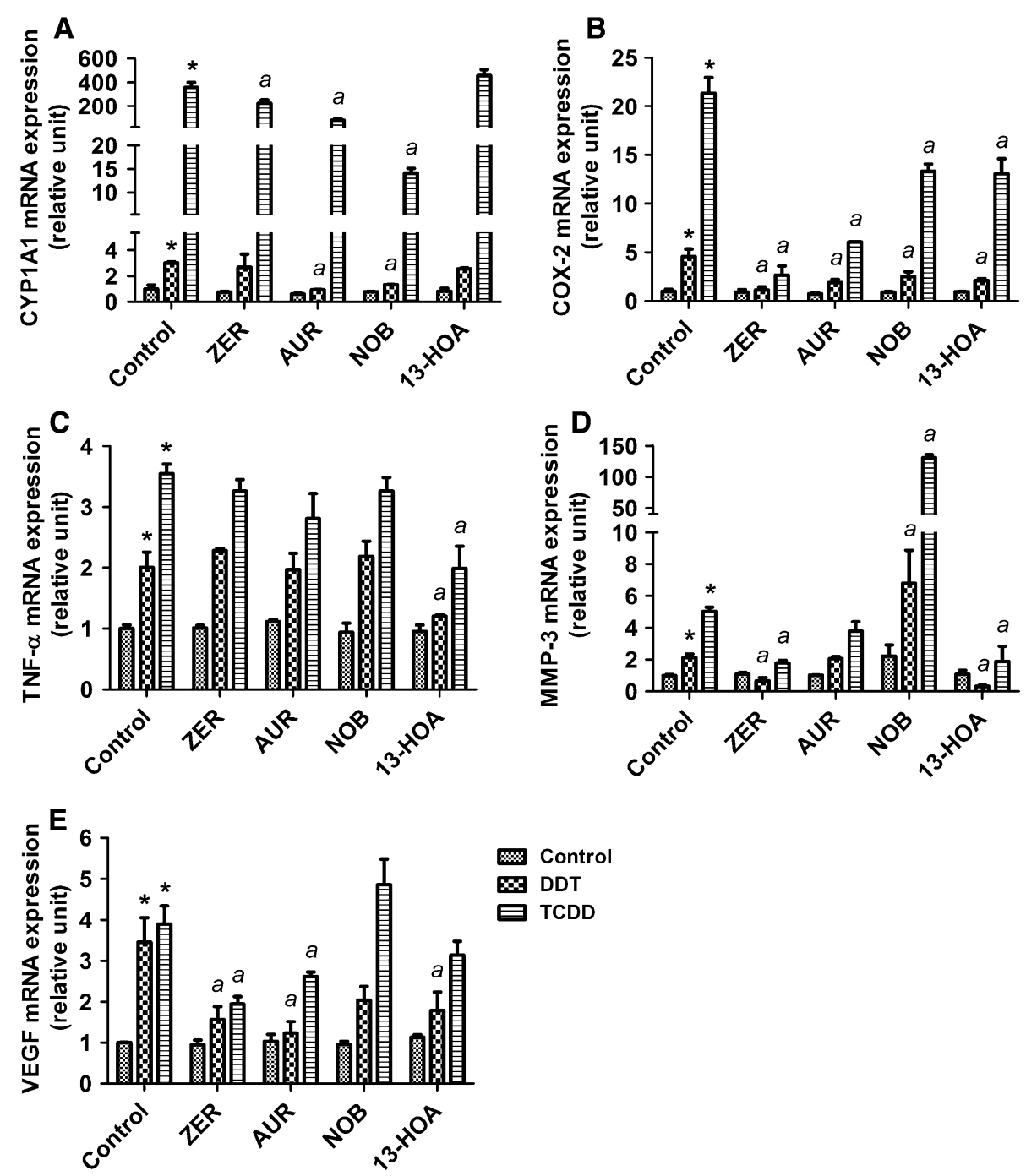

Assessment of inhibitory action of zerumbone on the mouse COX-2 gene activation using two COX-2-Luc reporter plasmids and EMSA

To confirm the inhibitory action of zerumbone on COX-2 expression, we tested its effect on the COX-2 gene activation using two COX-2-luciferase reporter plasmids on a kidney tubular epithelial cell model (MMDD1), since the active form of COX enzyme in this cell line mostly consists of COX-2, and since it is known to be very sensitive to the action of TCDD (Dong et al. 2010). The larger plasmid contains a near full length mouse COX-2 promoter ligated to a Luc gene, and the shorter one, in contrast, contains only the short segment of its promoter, which includes the CCAAT/enhancer binding protein (C/EBP) response element that is located close to the start codon. The results summarized in Fig. 3 show that zerumbone is effective in suppressing the COX-2 gene activating function of TCDD in both reporter transfected MMDD1 cell samples.
The observation that the inhibitory potency of zerumbone is similar in both COX-2 reporter assay supports the notion that the potencies of zerumbone is likely due to its ability to interfere with binding of C/EBP proteins to its response element. These findings are supported by current EMSA results indicating increased binding activity of the C/EBP element of the COX-2 promoter activated by TCDD (Fig. 3b, lane 2). In addition, supershift analysis of C/EBP element binding activity indicates that $\mathrm{C} / \mathrm{EBP} \beta$ is the active isoform involved in the observed TCDD-mediated increase in binding affinity (Fig. 3b, lane 4). Cells co-treated with zerumbone and TCDD (Fig. 3c, lane 4) showed significantly less binding activity of $\mathrm{C} / \mathrm{EBP}$ compared to cells treated with TCDD alone (Fig. 3c, lane 2).

Effects of auraptene on the TCDD- and DDT-mediated generation of intracellular ROS

The data from Fig. 4 show that treatment with either $1 \mu \mathrm{M}$ DDT or $10 \mathrm{nM}$ TCDD for $40 \mathrm{~min}$ in the human 
Fig. 3 Assessment of inhibitory action of zerumbone on the function of mouse COX-2 gene activation, as measured in the mouse MMDD1 model cells. a Cells were transiently transfected with the pCOX-2-Luc reporter plasmid using the luciferase assay.

The longer plasmid contains the near full length mouse COX-2 promoter, and the shorter plasmid contains only the C/EBP response element that is adjacent to the start codon. MMDD1 cells were pre-treated with $2 \mu \mathrm{M}$ zerumbone for $1 \mathrm{~h}$, followed by $10 \mathrm{nM}$ TCDD treatment for $20 \mathrm{~h}$. *Significantly different from control $P \leq 0.01$. a Significant lower than control $P \leq 0.01$. $b$ Significantly lower than TCDD treatment alone $P \leq 0.01$. b DNA binding activity of nuclear proteins from U937 macrophages to the $\mathrm{C} /$ EBP element of the COX-2 promoter. Cells were treated with $10 \mathrm{nM}$ TCDD or $0.1 \%$ DMSO (Vehicle control) for $3 \mathrm{~h}$. Antibodies for $\mathrm{C} / \mathrm{EBP} \alpha, \beta$, and $\delta$ isoforms were used in supershift analysis. A 100-fold excess of unlabeled oligonucleotide was added (Lane 6). C) DNA binding activity of nuclear proteins from U937 macrophages to the C/EBP element of the COX-2 promoter. Cells were treated with $10 \mathrm{nM}$ TCDD in absence (lane 2) or presence (lane 4) of $10 \mu \mathrm{M}$ zerumbone for $3 \mathrm{~h}$
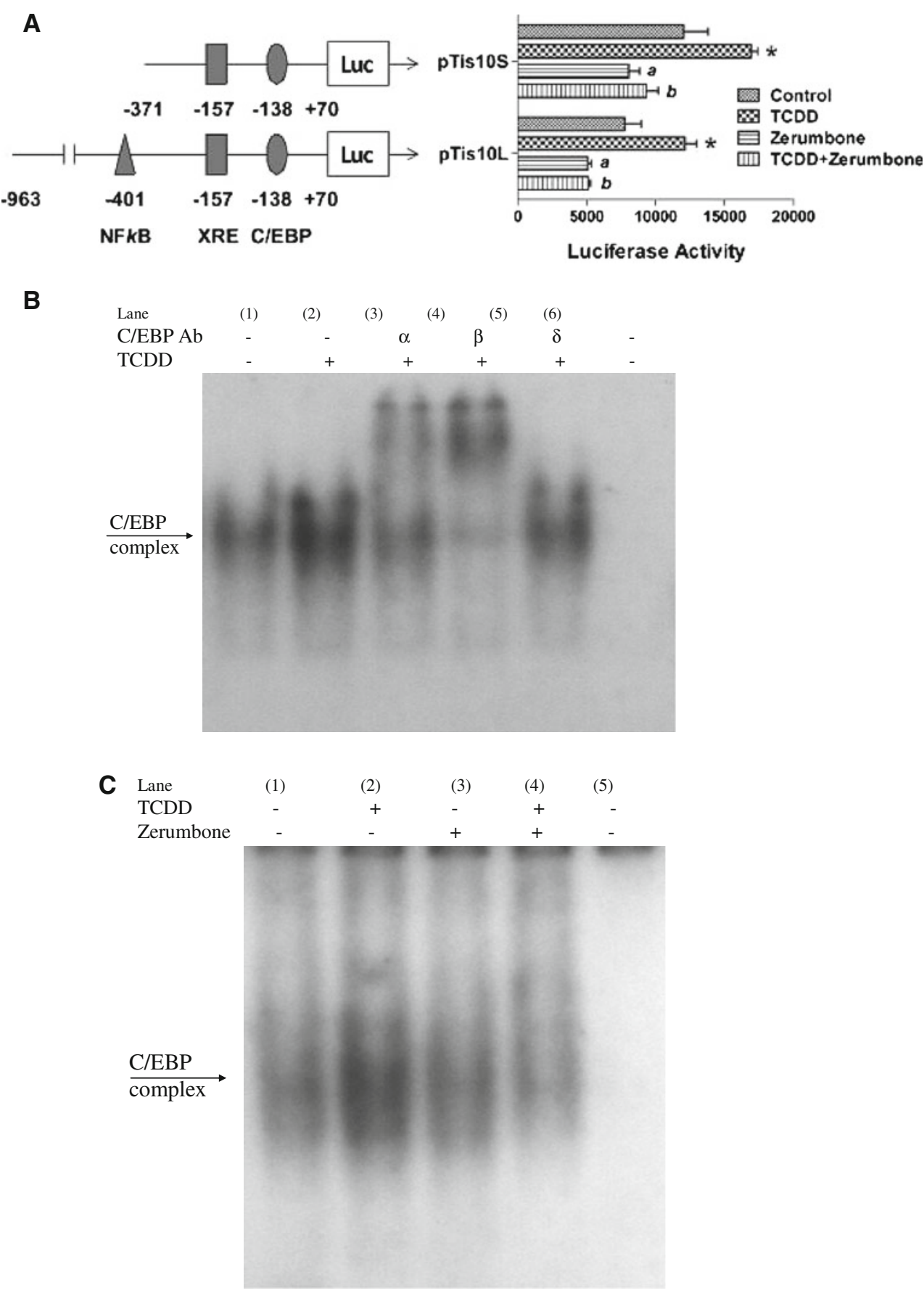

monocyte-derived macrophage U937 cell model results in significant differences in the generation of cellular ROS. Treatment with DDT results in a significant increase in ROS generation while that with TCDD results in a significant decrease (Fig. 4). Auraptene was the only phytochemical used in this assay, since previous work already showed that it possesses a high level of inhibition of $\mathrm{O}_{2}$-generation in differentiated HL-60 cells (Murakami et al. 1997), while showing no $\mathrm{O}_{2}$-scavenging potential. The results from Fig. 4 support this finding in that treatment with $20 \mu \mathrm{M}$ auraptene alone significantly reduces intracellular ROS generation. In addition, pre- treatment with auraptene prior to exposure with DDT results in the complete suppression of DDT-induced ROS generation. Pre-treatment of auraptene prior to TCDD treatment resulted in no significant change compared to TCDD treatment alone.

Effects of selected phytochemicals on the anti-apoptotic action of TCDD

Results in Fig. 5 show that activation of the AhR by TCDD significantly inhibits UV-induced apoptosis in the human lymphoma cell line U937 as in the case of MCF10A cells 


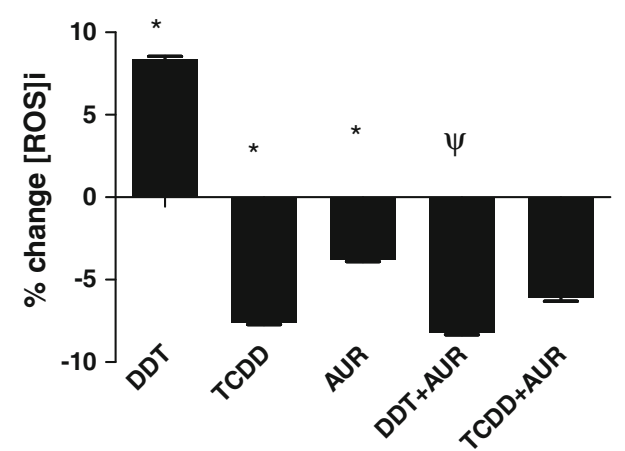

Fig. 4 Effects of $1 \mu \mathrm{M} p, p^{\prime}$-DDT and $10 \mathrm{nM}$ TCDD against the actions of $20 \mu \mathrm{M}$ auraptene $(A U R)$ on intracellular reactive oxygen species (ROS) formation for $40 \mathrm{~min}$ in a U937 macrophage model. Data are expressed in percent change in intracellular ROS formation compared to $0.1 \%$ DMSO-treated controls. * Treatment significantly different from controls $P<0.05, \psi$ treatment significantly different from TCDD or DDT treatment alone $P<0.05$

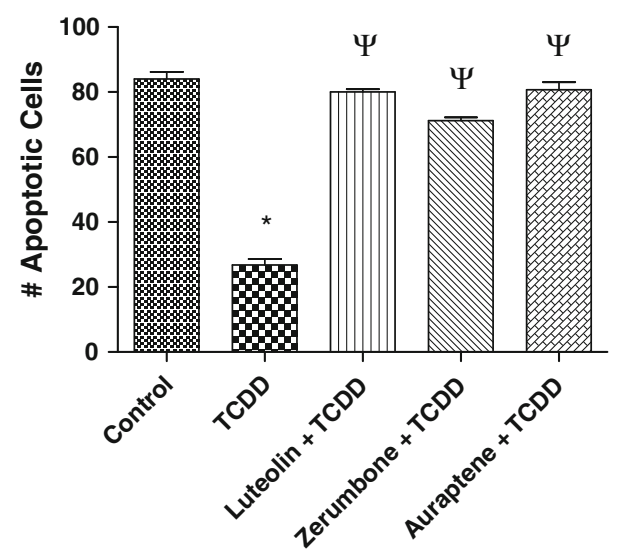

Fig. 5 Assessment of pro-apoptotic actions of phytochemicals against the anti-apoptotic effects of TCDD following UV-induced apoptosis in human U937 monocyte cells. Apoptosis was induced by UV light, and the number of apoptotic cells was determined after $4 \mathrm{~h}$. Cells were treated with $10 \mathrm{nM}$ TCDD for $48 \mathrm{~h}$ alone or pre-treated for $15 \mathrm{~min}$ with the indicated phytochemicals at the concentrations described in Fig. 2. Luteolin was treated at $10 \mu \mathrm{M}$. The data are presented as percent inhibition versus the respective controls. * Significantly different from control $P \leq 0.01$, $\psi$, significantly different from TCDD treatment alone $P \leq 0.01$

(Park and Matsumura 2006). The number of UV-induced apoptotic cells was reduced by $60 \%$ in U937 cells after treatment with $10 \mathrm{nM}$ TCDD for $48 \mathrm{~h}$. We then investigated, whether these phytochemicals, along with luteolin (used here as a positive control as a typical antagonist of the AhR; Zhang et al. 2003), are able to abolish the TCDDmediated inhibition of apoptosis (Fig. 5). Cells were treated with $10 \mathrm{nM}$ TCDD and then pre-treated for $1 \mathrm{~h}$ with the phytochemicals $10 \mu \mathrm{M}$ luteolin, $10 \mu \mathrm{M}$ zerumbone, or $20 \mu \mathrm{M}$ auraptene. Zerumbone eliminated the anti-apoptotic effect of TCDD by about $80 \%$ in vitro. The AhR antagonist luteolin as well as auraptene abolished the anti-apoptotic effect of TCDD significantly by about $90 \%$.

\section{Discussion}

It is well known that most of the toxic actions of TCDD, if not all actions, are mediated by its specific receptor, the aryl hydrocarbon receptor (AhR; Hankinson 2005). This makes it relatively simple to recognize the specific action of TCDD by choosing a marker, which is most indicative of the actions mediated by the AhR. CYP1A1 is one such well-accepted marker that serves as an indicator of AhR activation in most cells, including this U937 human macrophage cell line (Komura et al. 2001). In this cell line, TCDD has been shown to induce inflammatory responses, leading to the lipid/cholesterol-accumulating "foam" cell phenotype (Vogel et al. 2004a). On the other hand, the action of DDT to induce typical cell stress responses among "non-excitable cells" is not directly mediated by any specific receptors; rather such actions of $p, p^{\prime}$-DDT are likely to be mediated by its direct actions on cellular $\mathrm{Ca} 2+$ homeostasis (Younglai et al. 2004) and activation of cell stress responses including inflammation (Dutta et al. 2008). For example, according to Frigo et al. (2004), $p, p^{\prime}$ DDT as well as $o, p^{\prime}$-DDT stimulation results in functional activation of AP-1 proteins, which are nuclear transcription factors controlling mitotic as well as cell stress response signaling in an endometrial adenocarcinoma cell line. In addition, there is a growing body of information pointing to the action of DDT to induce oxidative stress (PerezMaldonado et al. 2005; Slaninova et al. 2009). The data shown in Fig. 4 emphasize this point in that the extent of DDT-induced rapid generation of ROS, an indicator of oxidative stress, was much more pronounced than that of TCDD in U937 macrophages. This set of data is supported by our own observations that most of the inflammatory effects of DDT occurring within 30 min of addition of DDT can be attenuated by pre-treatment with $\mathrm{N}$-acetylcysteine, a well-accepted antagonist for oxidative damage (data not shown). Indeed, auraptene has been found in the current study to be most effective in suppressing COX-2 and VEGF expressions that were induced by DDT (Fig. 2). This finding supports the observation made by Jackson et al. (2007) that oxidative stress does indeed result in the up-regulation of VEGF expression in macrophages.

Many of these phytochemicals selected here for our studies have been studied previously in conjunction with their therapeutic anti-cancer studies using phorbol esters, such as the cancer promoter 12-O-tetradecanoylphorbol13-acetate (TPA; Kim et al. 2002). Therefore, it is highly relevant to compare the results of the current study to some of these previous studies. Zerumbone (Fig. 1) is a sesquiterpene found in rhizomes of Zingiber zerumbet Smith (Zingiberaceae) and was first identified as a potent suppressor of tumor promoter (TPA)-induced Epstein-Barr virus activation in Raji cells (Murakami et al. 1999). In this regard, 
the finding from the current study that zerumbone is the most effective suppressor of the actions of both DDT and TCDD to up-regulate COX-2 mRNA in U937 macrophages agrees with the previous diagnosis of the main action of this phytochemical to inhibit COX-2 in other types of cells (Murakami et al. 2002; Murakami et al. 2003). Interestingly, it showed no effect on TNF- $\alpha$ expression, meaning that the action spectrum of zerumbone is relatively specific: i.e. COX-2 and its down-stream signaling components. The inhibition of TCDD-mediated COX-2 activation by treatment with zerumbone appears to be the result of its interference with C/EBP- $\beta$ binding to its respective DNA binding element (Fig. 3b). This data support our laboratory's previous finding that TCDD treatment results in the activation of COX-2 via C/EBP- $\beta$ transcription (Vogel et al. 2004b). COX-2 activation leads to increased production of prostaglandins, which are known to elicit inflammatory responses in macrophages (Cuccurullo et al. 2007), and therefore specific inhibition of COX-2 by this phytochemical could explain a variety of events known to be suppressed by this compound, such as that of free radical formation, pro-inflammatory protein synthesis, and cancer cell proliferation.

Auraptene (Fig. 1) is a citrus coumarin that has been reported to repress experimental carcinogenesis in numerous tissues (Tanaka et al. 1997; Tanaka et al. 1998). Auraptene has also showed a high level of inhibition of $\mathrm{O}_{2}$-generation in differentiated HL-60 cells (Murakami et al. 1997), while possessing no $\mathrm{O}_{2}$-scavenging potential. Auraptene has been postulated to inhibit the assembly or activities of the NADPH oxidase system (Murakami et al. 1997); however, its distinct action mechanism has yet to be elucidated. Based on our data in Fig. 2, auraptene most significantly suppressed CYP1A1 mRNAs following exposure to TCDD and to a lesser extent DDT; in addition, it most effectively inhibited TCDD and DDTinduced ROS formation (Fig. 4). Viewed in this way, the observation that its action to preferentially suppress CYP1A1 as well as COX-2 expression that was induced by TCDD when compared to that by DDT can be better understood. While such an interpretation helps to explain also its suppressive effect on VEGF, one crucial difference between the action of zerumbone and auraptene is on the DDT-induced expression of MMP-3 (Fig. 2d), which makes it unlikely that inhibition of COX-2 can explain all of the effects of DDT and TCDD (as mentioned earlier, there exist notable differences in the earlier events elicited by DDT and TCDD as it pertains to oxidative stress and intracellular ROS generation (Fig. 4)). DDT treatment resulted in a significant increase in ROS generation while treatment with TCDD resulted in a significant suppression of ROS. Pre-treatment with auraptene resulted in a complete suppression of this DDT-induced increase on ROS generation, while having no effect on the TCDD-mediated suppression of cellular ROS (Fig. 4). In this way, auraptene may be regarded as an antioxidative agent as shown by our previous work (Murakami et al. 1997) and others (Soltani et al. 2010). Based on these observations and considerations, the likely candidate for the main action site of auraptene could be monooxygenase enzyme activities. Having explained the difference in the main action mechanisms of TCDD and DDT, it is also important to offer an explanation on the effectiveness of zerumbone and auraptene in suppressing both the COX-2- and VEGF-inducing actions of these two toxicants. One of the reasons for such overlaps in action spectra of these phytochemicals may be that both COX-2 and VEGF mRNA expressions could be induced by either inflammatory or oxidative stimuli. Therefore, it is possible that even though each phytochemical may be affecting only one of those two pathways; the end-result of their actions may overlap.

With regard to the results of our apoptosis study, we have previously described that treatment with TCDD to U937 monocyte cells results in an inhibition of UV-induced apoptosis and is associated with an increase in COX-2 expression (Vogel et al. 2007). Since most, if not all of these phytochemicals have been shown to suppress COX-2 expressions (Fig. 2b); this way of explaining the protective actions of these phytochemicals against the anti-apoptotic action of TCDD appear to be reasonable.

\section{Conclusion}

It must be re-emphasized here that the main objective of this study has been to identify the most effective phytochemical(s) antagonizing the action of TCDD and DDT to be potentially used to mitigate toxic effects of these toxicants. From this point of view, our main conclusion is that by far the most promising compound found is zerumbone, followed by auraptene, as judged by its action on COX-2 (Fig. 2b). The same trend was also observed on their action on VEGF (Fig. 2e), supporting the above conclusion. Thus, although there were some interesting effects of other phytochemicals, depending on the markers chosen, their importance in the current investigation deems to be minor, and therefore may not warrant in-depth discussions. In conclusion, we could demonstrate in the current study that zerumbone and auraptene are effective antagonizers of cell stress induced by two of the most powerful and persistent environmental pollutants. We could also explain some specific actions of these phytochemicals mechanistically for each pollutant. For instance, zerumbone appears to owe its unique property to specifically suppressing COX-2 against the actions of both DDT and TCDD. 
Acknowledgments Supported by research grant \#FAS0703859 from the Susan G. Komen for the Cure Program and two NIH research grants R01-ES0-5233, R21ES15846 and P30-ES05707 from the National Institute of Environmental Health Sciences, Research Triangle Park, North Carolina, USA. Supported in part by American Heart Association Western Affiliate 0765056Y.

Open Access This article is distributed under the terms of the Creative Commons Attribution Noncommercial License which permits any noncommercial use, distribution, and reproduction in any medium, provided the original author(s) and source are credited.

\section{References}

Altinoz MA, Korkmaz R (2004) NF-kappab, macrophage migration inhibitory factor and cyclooxygenase-inhibitions as likely mechanisms behind the acetaminophen- and nsaid-prevention of the ovarian cancer. Neoplasma 51(4):239-247

Ashida H (2000) Suppressive effects of flavonoids on dioxin toxicity. Biofactors 12(1-4):201-206

Charles GD, Shiverick KT (1997) 2, 3, 7, 8-tetrachlorodibenzo-pdioxin increases mrna levels for interleukin-1beta, urokinase plasminogen activator, and tumor necrosis factor-alpha in human uterine endometrial adenocarcinoma rl95-2 cells. Biochem Biophys Res Commun 238(2):338-342

Cuccurullo C, Fazia ML, Mezzetti A, Cipollone F (2007) Cox-2 expression in atherosclerosis: the good, the bad or the ugly? Curr Med Chem 14(15):1595-1605

Dong B, Nishimura N, Vogel CF, Tohyama C, Matsumura F (2010) Tcdd-induced cyclooxygenase- 2 expression is mediated by the nongenomic pathway in mouse mmdd 1 macula densa cells and kidneys. Biochem Pharmacol 79(3):487-497

Dutta R, Mondal AM, Arora V, Nag TC, Das N (2008) Immunomodulatory effect of ddt (bis[4-chlorophenyl]-1, 1, 1-trichloroethane) on complement system and macrophages. Toxicology 252(1-3): $78-85$

Frigo DE, Tang Y, Beckman BS, Scandurro AB, Alam J, Burow ME, McLachlan JA (2004) Mechanism of ap-1-mediated gene expression by select organochlorines through the p38 mapk pathway. Carcinogenesis 25(2):249-261

Hankinson O (2005) Role of coactivators in transcriptional activation by the aryl hydrocarbon receptor. Arch Biochem Biophys 433(2):379-386

Inoue Y, Tsushima H, Ando K, Sawayama Y, Sakai M, Yamasaki R, Matsuo E, Tsutsumi C, Imaizumi Y, Iwanaga M, Imanishi D, Taguchi J, Miyazaki Y, Tomonaga M (2006) Chemokine expression in human erythroid leukemia cell line as-e2: macrophage inflammatory protein-3alpha/ccl20 is induced by inflammatory cytokines. Exp Hematol 34(1):19-26

Jackson IL, Chen L, Batinic-Haberle I, Vujaskovic Z (2007) Superoxide dismutase mimetic reduces hypoxia-induced o $2 *_{-}$, tgf-beta, and vegf production by macrophages. Free Radic Res 41(1):8-14

Kim HW, Murakami A, Nakamura Y, Ohigashi H (2002) Screening of edible japanese plants for suppressive effects on phorbol esterinduced superoxide generation in differentiated hl-60 cells and as 52 cells. Cancer Lett 176(1):7-16

Komura K, Hayashi S, Makino I, Poellinger L, Tanaka H (2001) Aryl hydrocarbon receptor/dioxin receptor in human monocytes and macrophages. Mol Cell Biochem 226(1-2):107-118

Kraemer SA, Arthur KA, Denison MS, Smith WL, DeWitt DL (1996) Regulation of prostaglandin endoperoxide $\mathrm{h}$ synthase-2 expression by 2, 3, 7, 8,-tetrachlorodibenzo-p-dioxin. Arch Biochem Biophys 330(2):319-328
Lappas M, Permezel M, Georgiou HM, Rice GE (2002) Nuclear factor kappa $\mathrm{b}$ regulation of proinflammatory cytokines in human gestational tissues in vitro. Biol Reprod 67(2):668-673

Matsunaga Y, Koda M, Murawaki Y (2004) Expression of matrix metalloproiteinases (mmps) and tissue inhibitors of metalloproteinases (timps) in hepatocellular carcinoma tissue, compared with the surrounding non-tumor tissue. Res Commun Mol Pathol Pharmacol 115-116:143-150

Murakami A, Ohigashi H (2007) Targeting nox, inos and cox-2 in inflammatory cells: chemoprevention using food phytochemicals. Int J Cancer 121(11):2357-2363

Murakami A, Kuki W, Takahashi Y, Yonei H, Nakamura Y, Ohto Y, Ohigashi H, Koshimizu K (1997) Auraptene, a citrus coumarin, inhibits 12-o-tetradecanoylphorbol-13-acetate-induced tumor promotion in icr mouse skin, possibly through suppression of superoxide generation in leukocytes. Jpn J Cancer Res 88(5):443-452

Murakami A, Takahashi M, Jiwajinda S, Koshimizu K, Ohigashi H (1999) Identification of zerumbone in zingiber zerumbet smith as a potent inhibitor of 12-o-tetradecanoylphorbol-13-acetateinduced epstein-barr virus activation. Biosci Biotechnol Biochem 63(10): 1811-1812

Murakami A, Takahashi D, Kinoshita T, Koshimizu K, Kim HW, Yoshihiro A, Nakamura Y, Jiwajinda S, Terao J, Ohigashi H (2002) Zerumbone, a southeast asian ginger sesquiterpene, markedly suppresses free radical generation, proinflammatory protein production, and cancer cell proliferation accompanied by apoptosis: the alpha, beta-unsaturated carbonyl group is a prerequisite. Carcinogenesis 23(5):795-802

Murakami A, Matsumoto K, Koshimizu K, Ohigashi H (2003) Effects of selected food factors with chemopreventive properties on combined lipopolysaccharide- and interferon-gamma-induced ikappab degradation in raw264.7 macrophages. Cancer Lett 195(1):17-25

Nishimura N, Matsumura F, Vogel CF, Nishimura H, Yonemoto J, Yoshioka W, Tohyama C (2008) Critical role of cyclooxygenase-2 activation in pathogenesis of hydronephrosis caused by lactational exposure of mice to dioxin. Toxicol Appl Pharmacol 231(3):374-383

Park S, Matsumura F (2006) Characterization of anti-apoptotic action of tcdd as a defensive cellular stress response reaction against the cell damaging action of ultra-violet irradiation in an immortalized normal human mammary epithelial cell line, mcf10a. Toxicology 217(2-3):139-146

Perez-Maldonado IN, Herrera C, Batres LE, Gonzalez-Amaro R, DiazBarriga F, Yanez L (2005) Ddt-induced oxidative damage in human blood mononuclear cells. Environ Res 98(2):177-184

Rozen S, Skaletsky HJ (2003) Primer3 on the www for general users and for biologist programmers. In: Krawetz S, Misener S (eds) Bioinformatics methods and protocols: methods in molecular biology. Humana Press, Totowa, pp 365-386

Sciullo EM, Vogel CF, Li W, Matsumura F (2008) Initial and extended inflammatory messages of the nongenomic signaling pathway of the tcdd-activated ah receptor in u937 macrophages. Arch Biochem Biophys 480(2):143-155

Shibuya M (2006) Differential roles of vascular endothelial growth factor receptor-1 and receptor-2 in angiogenesis. J Biochem Mol Biol 39(5):469-478

Slaninova A, Smutna M, Modra H, Svobodova Z (2009) A review: oxidative stress in fish induced by pesticides. Neuro Endocrinol Lett 30(Suppl 1):2-12

Soltani F, Mosaffa F, Iranshahi M, Karimi G, Malekaneh M, Haghighi F, Behravan J (2010) Auraptene from ferula szowitsiana protects human peripheral lymphocytes against oxidative stress. Phytother Res 24(1):85-89

Tanaka T, Kawabata K, Kakumoto M, Makita H, Hara A, Mori H, Satoh K, Murakami A, Kuki W, Takahashi Y, Yonei H, 
Koshimizu K, Ohigashi H (1997) Citrus auraptene inhibits chemically induced colonic aberrant crypt foci in male f344 rats. Carcinogenesis 18(11):2155-2161

Tanaka T, Kawabata K, Kakumoto M, Hara A, Murakami A, Kuki W, Takahashi Y, Yonei H, Maeda M, Ota T, Odashima S, Yamane T, Koshimizu K, Ohigashi H (1998) Citrus auraptene exerts dose-dependent chemopreventive activity in rat large bowel tumorigenesis: the inhibition correlates with suppression of cell proliferation and lipid peroxidation and with induction of phase ii drug-metabolizing enzymes. Cancer Res 58(12):2550-2556

Taylor MJ, Lucier GW, Mahler JF, Thompson M, Lockhart AC, Clark GC (1992) Inhibition of acute tcdd toxicity by treatment with antitumor necrosis factor antibody or dexamethasone. Toxicol Appl Pharmacol 117(1):126-132

Vogel C, Schuhmacher US, Degen GH, Goebel C, Abel J (1997) Differential effects of 2,3,7,8-tetrachlorodibenzo-p-dioxin on the expression of prostaglandin-h synthase isoenzymes in mouse tissues. Adv Exp Med Biol 433:139-143

Vogel CF, Sciullo E, Matsumura F (2004a) Activation of inflammatory mediators and potential role of ah-receptor ligands in foam cell formation. Cardiovasc Toxicol 4(4):363-373
Vogel CF, Sciullo E, Park S, Liedtke C, Trautwein C, Matsumura F (2004b) Dioxin increases c/ebpbeta transcription by activating camp/protein kinase a. J Biol Chem 279(10):8886-8894

Vogel CF, Sciullo E, Wong P, Kuzmicky P, Kado N, Matsumura F (2005) Induction of proinflammatory cytokines and c-reactive protein in human macrophage cell line u937 exposed to air pollution particulates. Environ Health Perspect 113(11):1536-1541

Vogel CF, Li W, Sciullo E, Newman J, Hammock B, Reader JR, Tuscano J, Matsumura F (2007) Pathogenesis of aryl hydrocarbon receptormediated development of lymphoma is associated with increased cyclooxygenase-2 expression. Am J Pathol 171(5): 1538-1548

Younglai EV, Kwan TK, Kwan CY, Lobb DK, Foster WG (2004) Dichlorodiphenylchloroethylene elevates cytosolic calcium concentrations and oscillations in primary cultures of human granulosa-lutein cells. Biol Reprod 70(6):1693-1700

Zhang S, Qin C, Safe SH (2003) Flavonoids as aryl hydrocarbon receptor agonists/antagonists: effects of structure and cell context. Environ Health Perspect 111(16):1877-1882 